\title{
Genetic and epigenetic changes induced by chronic low dose exposure to arsenic of mouse testicular Leydig cells
}

\author{
KAMALESHWAR P. SINGH and JAMES W. DuMOND Jr
}

\author{
Department of Biology, Texas Southern University, Houston, TX 77004, USA
}

Received April 26, 2006; Accepted June 28, 2006

\begin{abstract}
Arsenic is an important environmental carcinogen that affects millions of people worldwide through contaminated water supplies. Genotoxicity of arsenic has been a topic of controversy. Both genetic alterations (mutations) and epigenetic changes (methylation) have been shown to play a crucial role in environmental carcinogenesis. Chronic exposure to arsenic has been shown to induce malignant transformation of mammalian cells. However, the genetic aberrations induced by arsenic in this process are unclear. The purpose of this study was to determine if both lower $(1 \mathrm{pg} / \mathrm{ml})$ and higher concentrations $(100 \mathrm{ng} / \mathrm{ml})$ of arsenic induces either mutations or methylation changes that could lead to the development of genomic instability in TM3 cells, immortalized Leydig cells derived from normal mouse testis. Two independent exposure times were used in this study which resulted in cells of 33 and 100 generations in age. Arsenic-induced genetic and epigenetic changes were screened at a genome-wide level by random amplified polymorphic DNA (RAPD), also known as AP-PCR method with undigested DNA as well as DNA digested by the methylation sensitive isosizomeric restriction enzymes MSPI and HpaII and untreated controls. Changes in the DNA fingerprint of both, the restriction enzyme digested DNA (indicating methylation changes) as well as undigested DNA (indicating mutations) from arsenic-treated (low as well as high dose) samples were observed as compared to their controls. Thus, this study provides the first evidence at DNA sequence level for mutagenic potential of arsenic. Further characterization of these altered genomic regions is underway. The understanding of these genetic and epigenetic changes in arsenic-induced carcinogenesis will provide a basis for better interventional approaches in both the treatment and prevention of arsenicinduced cancer.
\end{abstract}

\section{Introduction}

Inorganic arsenic is considered to be one of the most hazardous substances in the United States, primarily because of its well

Correspondence to: Dr Kamaleshwar P. Singh, Department of Biology, Texas Southern University, 3100 Cleburne Avenue, Houston, TX 77004, USA

E-mails: singhk@tsu.edu; kamaleshwar9@aol.com

Key words: arsenic, mutations, DNA methylations, random amplified polymorphic DNA established human carcinogenic potential and chance of exposure to US populations $(1,2)$. Arsenic, as trivalent arsenite $\left(\mathrm{AS}^{3+}\right)$ or pentavalent arsenate $\left(\mathrm{AS}^{5+}\right)$, is naturally occurring and is ubiquitous in environment. It is released into the environment via agricultural and industrial processes as well as medical applications (3). However, drinking water is the most common source of arsenic exposure for the general population and is a serious environmental problem (4). Higher levels of arsenic in drinking water and the associated adverse health effects are found in many developing areas around the world, including China, India, Mexico, and Bangladesh (2). Recent reports indicate that lower levels of arsenic, such as those found in drinking water in many areas of the United States, may also exert a carcinogenic risk to humans $(5,6)$.

Human exposure to arsenic can cause both short- and longterm health effects. Long or chronic effects occur over many years and long-term exposure to arsenic has been linked to cancer of the bladder, lungs, skin, kidneys, and nasal passages, liver and prostate. Long-term exposure to low doses of arsenite has been shown to transform non-tumorigenic human keratinocytes to cells that were tumorigenic in nude mice (7). Chronic arsenic exposure of the non-tumorigenic human prostate epithelial cells to low levels of sodium arsenite resulted in malignant transformation and produced tumorigenic cells (8). Thus, the carcinogenic potential of arsenic is well established, however the mechanism of arsenic-induced carcinogenesis is not clear.

Various mechanisms, both genotoxic and non-genotoxic, have been proposed to explain the carcinogenicity of arsenic at the cellular and molecular levels $(9,10)$. Genomic DNA hypomethylation and K-ras oncogene activation without mutations has been reported in arsenic-induced malignant transformation of human prostate epithelial cells (8). Longterm exposure of mice to arsenic in drinking water has been shown to induce global DNA hypomethylation in liver tissue (11). Arsenic-induced promoter hypermethylation of tumor suppressor gene, RASSF1A and PRSS3 has been suggested to play a role in human bladder cancer (12). Arsenic treatment of Sprague-Dawley rats results in structural chromosomal aberrations in bone-marrow cells (13). These studies clearly indicate that arsenic induces methylation changes. There are reports providing indirect evidence that arsenic has mutagenic properties based on the fact it can induce apoptosis $(14,15)$. However, there are no reports of arsenic-induced mutations at the sequence level in cells with either chronic arsenic treatment or during arsenic-induced malignant transformation of cells. The critical sequence of molecular events involved 
in arsenic-induced carcinogenesis is not clear. Moreover, evidence at molecular level for the genotoxicity of lower doses of arsenic is lacking.

Studies over the past few decades have identified numerous genetic alterations in neoplastic cells, providing overwhelming evidence for the genetic basis of human cancers (16). All tumors contain genetic alterations, including subtle changes in DNA sequence and point mutations $(17,18)$. Mutations in a minimum of six to seven genes are crucial to the process of cancer development (19). It is in this context that the detection of the target genomic regions susceptible to mutations induced by chronic arsenic exposure is crucial for the identification of genes that may play a role in arsenic-induced carcinogenesis.

Random amplified polymorphic DNA (RAPD)/AP-PCR technique is a powerful tool for screening genetic alterations. Using this method, we have identified a novel mutation located at $17 \mathrm{q} 11.2$ in $80 \%$ of the sporadic breast tumor samples analyzed (20). Recently, we have reported somatic mutations in diethylstilbestrol-induced kidney tumors in Syrian hamsters $(21,22)$. In this study, by using the arbitrary primed-PCR (AP-PCR) assay we identified both genetic (mutation) and epigenetic (methylation) changes induced by arsenic in mouse testicular Leydig cells. We have performed a comprehensive analysis of the genotoxic potential of arsenic by including the short- as well as long-term exposed cells to various arsenic concentrations.

\section{Materials and methods}

Chemicals. We purchased sodium arsenite (NaAsO2; purity, 96.6\%) from Sigma Chemical Co. (St. Louis, MO), and AmpliTaq DNA polymerase (Stoffel fragment), dNTPs and mineral oil from PE Applied Biosystems, Foster City, CA. The enzyme assay buffers, 10X Stoffel buffer $(100 \mathrm{mM} \mathrm{KCl}$; 100 mM Tris-HCl, pH 8.3), was received from Applied Biosystems along with the corresponding enzymes. Sets of twenty OPA, OPC, OPK, OPE, OPAA and OP 26 oligonucleotide random 10-mer primers were purchased from Operon Technologies (Alameda, CA). Restriction enzymes with reaction buffers were purchased from Roche Applied Sciences (Indianapolis, IN, USA).

Cell culture and treatment. Mouse testicular Leydig cells (TM3), were obtained from ATCC (CRL-1714) and propagated in DMEM/F12 growth medium supplemented with 5\% horse serum and $2.5 \%$ fetal bovine serum. TM3 cells are immortalized but non-tumorigenic Leydig cells derived from normal mouse testes. Cultures were incubated at $37^{\circ} \mathrm{C}$ in a humidified atmosphere containing $5 \% \mathrm{CO}_{2}$. For continuous exposure of cells to sodium arsenite, we followed the earlier published approach that have shown arsenic-induced transformation of human $\mathrm{HaCaT}$ keratinocytes (7) and prostate epithelial cells (8). Cells were grown in the culture medium containing sodium arsenite at concentrations of $1 \mathrm{ng} / \mathrm{ml}$, $100 \mathrm{ng} / \mathrm{ml}$, and $1 \mu \mathrm{g} / \mathrm{ml}$. The cell cultures were grown to approximately $80 \%$ confluence and then were subcultured in medium containing sodium arsenite. This process has been previously reported by our laboratory (Harmon $\mathrm{N}$ and DuMond JW, Society of Toxicology Annual Meeting, Baltimore, MD, 2004). For each concentration tested (including control), a total of 3 flasks were ran in parallel. Using this approach the cells were grown in sodium arsenite containing medium for either 5 or 15 passages. Given the relatively short cell cycle time of TM3 cells $(\approx 18 \mathrm{~h})$, the cells isolated for analysis had been exposed for a total of 33 and 100 generations respectively. Control cultures grown in arsenic free medium (treated with vehicle, sterile deionised water) were used as passage-matched controls.

DNA extraction. Genomic DNAs were isolated from arsenictreated and control (treated with vehicle) groups of TM3 cells following the methods as described previously by us (23). The DNA and RNA were quantified spectrophotometrically and purity as well as integrity was checked by ethidium bromide staining after resolving on $1.0 \%$ agarose gel.

$R A P D-P C R$. RAPD-PCR was performed on DNA from arsenic-treated and untreated control group of TM3 cells using a previously described method (23). An aliquot of $2 \mu \mathrm{g}$ DNA was incubated at $37^{\circ} \mathrm{C}$ separately with methylation sensitive restriction enzyme, MSPI, and methylation insensitive restriction enzyme HPAII. After overnight incubation for complete digestion of DNA, the restriction enzyme was heatdenatured by incubation at $70^{\circ} \mathrm{C}$ for $10 \mathrm{~min}$. The digested DNA samples were then diluted to $20 \mathrm{ng} / \mu \mathrm{l}$ for RAPD analysis. Briefly, the PCR amplifications were performed in $25 \mu 1$ of reaction mixture containing $2.5 \mu 1$ of $10 \mathrm{X}$ enzyme assay buffer, $100 \mu \mathrm{M}$ each of dATP, dCTP, dGTP and dTTP, $100 \mathrm{nM}$ of random (10-bp) primer, $1.5 \mathrm{mM} \mathrm{MgCl}_{2}, 1.5 \mathrm{U}$ of AmpliTaq DNA polymerase (Stoffel fragment) and $75 \mathrm{ng}$ of either undigested or restriction enzyme-digested DNA as template. The amplification was performed in a Perkin-Elmer Cetus DNA thermal cycler programmed for 45 cycles as follows: 1st cycle of $3.5 \mathrm{~min}$ at $92^{\circ} \mathrm{C}, 1 \mathrm{~min}$ at $34^{\circ} \mathrm{C}, 2 \mathrm{~min}$ at $72^{\circ} \mathrm{C}$, plus 44 cycles of $1 \mathrm{~min}$ at $92^{\circ} \mathrm{C}, 1 \mathrm{~min}$ at $34^{\circ} \mathrm{C}, 2 \mathrm{~min}$ at $72^{\circ} \mathrm{C}$, followed by a final extension cycle of $15 \mathrm{~min}$ at $72^{\circ} \mathrm{C}$. Amplified products were resolved on a $1.5 \%$ agarose gel and visualized by ethidium-bromide staining. Each experiment was repeated three to four times.

\section{Results}

Seventeen random 10-mer primers were used in RAPD-PCR fingerprinting to analyze the arsenic-induced genomic instability in TM3 cells. Fifteen out of a total seventeen primers used produced reproducible and scorable amplification fingerprints. Nine of the fifteen primers produced similar RAPD fingerprints from controls and arsenic-treated TM3 cells of both short as well as chronic treatment groups, rendering it uninformative in revealing alterations in DNA from arsenictreated cells. The remaining six primers detected changes in RAPD profiles of the arsenic-treated samples compared with untreated controls. The sequence of these six primers, total number of amplification products generated by these individual primers, variable fragments and their sizes in the fingerprints of arsenic-treated samples and untreated controls are described in Table I and representative RAPD fingerprints are shown in Figs. 1-6. Among these six primers, three (OPC11, OPC17, OPK14) detected mutations only, whereas one primer (OPC20) detected methylation changes only. The remaining two 
Table I. Summary of the gains, losses and intensity changes of RAPD-amplified loci in the fingerprints from DNA of arsenictreated samples and their controls. ${ }^{\mathrm{a}}$

\begin{tabular}{|c|c|c|c|c|c|c|c|c|c|c|c|c|c|}
\hline \multirow[b]{2}{*}{ Primer $\left(5^{\prime} \rightarrow 3^{\prime}\right)$} & \multirow[b]{2}{*}{ Duration } & \multicolumn{4}{|c|}{ Undigested DNA } & \multicolumn{4}{|c|}{ MspI digested DNA } & \multicolumn{4}{|c|}{ HpaII digested DNA } \\
\hline & & $\mathrm{T} / \mathrm{V}$ & $1 \mathrm{ng}$ & $100 \mathrm{ng}$ & $1 \mu \mathrm{g}$ & $\mathrm{T} / \mathrm{V}$ & $1 \mathrm{ng}$ & $100 \mathrm{ng}$ & $1 \mu \mathrm{g}$ & $\mathrm{T} / \mathrm{V}$ & $1 \mathrm{ng}$ & $100 \mathrm{ng}$ & $1 \mu \mathrm{g}$ \\
\hline OPC07 & $\mathrm{S}$ & & +1300 & +1300 & & & & & & & & & \\
\hline \multirow[t]{13}{*}{ (ATTCTGGTTT) } & & $8 / 8$ & -1200 & & -1200 & $6 / 6$ & & & & $4 / 4$ & & & \\
\hline & & & & +1000 & & & & $780^{-\mathrm{I}}$ & $780^{-\mathrm{I}}$ & & $780^{+1}$ & $780^{-\mathrm{I}}$ & $780^{-1}$ \\
\hline & & & & & +900 & & +700 & & +750 & & $750^{-\mathrm{I}}$ & -750 & -750 \\
\hline & & & +700 & +750 & & & +500 & +500 & +500 & & +510 & & \\
\hline & & & & & +500 & & -450 & & & & -500 & & \\
\hline & & & -300 & & & & -400 & & & & & & \\
\hline & $\mathrm{C}$ & & +1100 & +890 & +1100 & & & & +900 & & & +1000 & +1000 \\
\hline & & $6 / 6$ & & -780 & & $6 / 6$ & $780^{+1}$ & $780^{+1}$ & $780^{+1}$ & $8 / 8$ & & +900 & \\
\hline & & & & -750 & & & & & & & & $780^{+1}$ & +750 \\
\hline & & & -650 & -650 & & & +610 & +590 & +610 & & -610 & & $610^{+1}$ \\
\hline & & & & & & & & & +550 & & & +550 & \\
\hline & & & +500 & $+500^{+I}$ & & & $500^{-\mathrm{I}}$ & $500^{-\mathrm{I}}$ & -500 & & & -500 & \\
\hline & & & & & & & & & & & -300 & -300 & -300 \\
\hline OPC03 & $\mathrm{C}$ & & - & & - & & +1500 & +1500 & +1500 & & - & - & - \\
\hline \multirow[t]{2}{*}{ (GGGGGTCTTT) } & & $3 / 1$ & & & & $3 / 2$ & & & & $3 / 1$ & & & \\
\hline & & & & $890^{-\mathrm{I}}$ & & & & $890^{-\mathrm{I}}$ & & & & $890^{-1}$ & \\
\hline OPC20 & $\mathrm{C}$ & $6 / 0$ & & & & $6 / 1$ & & & & $3 / 1$ & +1100 & +1100 & \\
\hline (ACTTCGCCAC) & & & & & & & $600^{+1}$ & $600^{+1}$ & $600^{+1}$ & & & & \\
\hline $\begin{array}{l}\text { OPC17 } \\
\text { (TTCCCCCCAG) }\end{array}$ & $\mathrm{C}$ & $5 / 1$ & +1100 & +1100 & +1100 & & & & & & & & \\
\hline OPC11 & $\mathrm{C}$ & $4 / 2$ & +1000 & +1000 & +1000 & & & & & & & & \\
\hline (AAAGCTGCGG) & & & $700^{+1}$ & $700^{+1}$ & $700^{+1}$ & & & & & & & & \\
\hline $\begin{array}{l}\text { OPK14 } \\
\text { (CCCGCTACAC) }\end{array}$ & $\mathrm{C}$ & $7 / 1$ & -480 & -480 & -480 & & & & & & & & \\
\hline
\end{tabular}

${ }^{a}$ Fragment sizes of the amplification products are given in base pairs (bp). S, samples treated with arsenic for short term (5 passage); C, samples with chronic treatment (15 passage) of arsenic; $\mathrm{T}$, total number of amplification products; $\mathrm{V}$, number of variable products; ${ }^{-\mathrm{I}}$ reduction in intensity; ${ }^{+\mathrm{I}}$ increase in the intensity.

(OPC03, OPC07) detected both mutations as well as methylation changes. Together, these six primers revealed $48.7 \%$ (19/39, from undigested DNA) RAPD loci associated with arsenic-induced mutations and 78.26\% (18/23, from $M s p$ I and HpaII digested DNA) RAPD loci associated with arsenicinduced methylation changes. The detail descriptions of the loci showing arsenic-induced changes are as follows:

Loci without mutation or methylation changes (i.e. similar in control and arsenic-treated samples). Representative photo- graphs of monomorphic (similar loci) RAPD-PCR fingerprints generated by primer OPC15 from arsenic-treated samples and their controls are shown in Fig. 1. Nine of the fifteen primers produced similar RAPD fingerprints from controls and arsenic-treated TM3 cells of short (Fig. 1 upper panel) as well as chronic (Fig. 1, lower panel) treatment groups. Although the loci amplified with these nine primers were not informative in revealing arsenic-induced genetic alterations, loci without mutation/methylation changes indicate that RAPDPCR can detect not only genetically altered regions but 

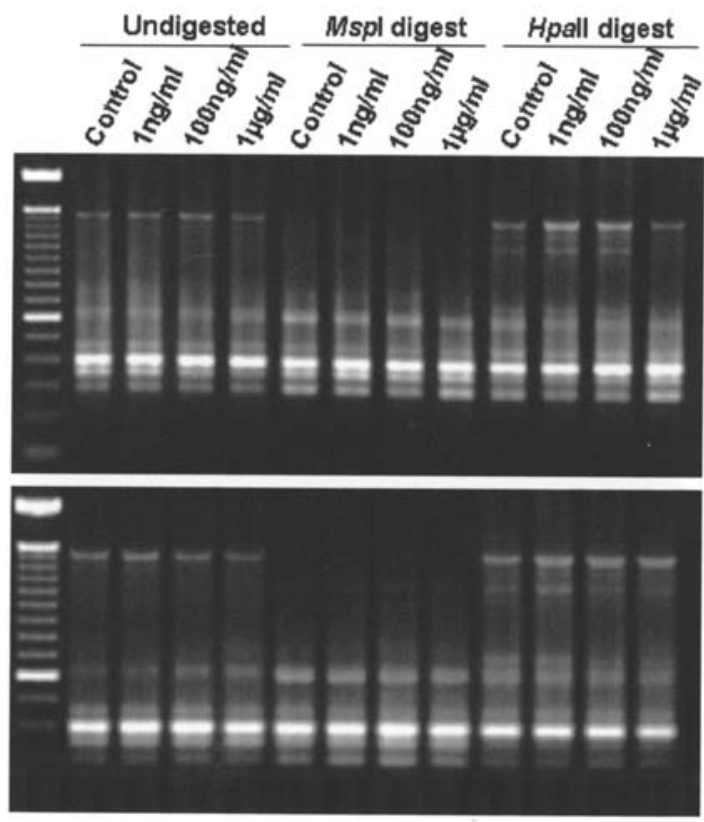

OPC15

Figure 1. Representative RAPD profiles from DNA (undigested as well as restriction enzyme $M s p \mathrm{I}$ and HpaII digested) of mouse testicular Leydig cells showing similar DNA fingerprint patterns between arsenic-treated cells ( $1 \mathrm{ng} / \mathrm{ml}, 100 \mathrm{ng} / \mathrm{ml}, 1 \mu \mathrm{g} / \mathrm{ml}$ ) and their control (treated with vehicle). Upper panel, RAPD profile from shorter treatment (5 passage) batch of cells; lower panel, RAPD profile from chronic treatment (15 passage) batch of cells. Primer (OPC15) used for both, upper and lower panels is given at the bottom of fingerprint.

also genomic regions that have not been affected by arsenic treatment. The simultaneous amplification of both the affected regions and unaffected regions of the genome validates the sensitivity and reliability of RAPD-PCR fingerprinting.

Loci susceptible to arsenic-induced mutation. Comparison of fingerprints generated from the undigested DNA of arsenictreated samples with their control revealed some loci showing changes indicating arsenic-induced mutations. The loci showing changes, their size and the doses $(1 \mathrm{ng} / \mathrm{ml}, 100 \mathrm{ng} / \mathrm{ml}$, and $1 \mu \mathrm{g} / \mathrm{ml}$ ) as well as duration of arsenic treatments (33 or 100 generations) with which it was detected are summarized in Table I. These mutational changes resulted in either complete loss or gain of the loci, or changes in the intensity of the loci. For example, irrespective of the doses $(1 \mathrm{ng} / \mathrm{ml}, 100 \mathrm{ng} / \mathrm{ml}$, $1 \mu \mathrm{g} / \mathrm{ml}$ ) of arsenic used for treatment, a gain of $1100 \mathrm{bp}$ RAPD amplified locus with primer OPC17, and loss of $480 \mathrm{bp}$ locus with primer OPK14 was observed in the fingerprints of chronic arsenic-treated samples as compared to their controls (Fig. 2, Table I). Similarly, the gain of $1000 \mathrm{bp}$ locus and gain in the intensity of 700 bp locus with primer OPC11 was observed in fingerprints of DNA from all the three $(1 \mathrm{ng} / \mathrm{ml}$, $100 \mathrm{ng} / \mathrm{ml}, 1 \mu \mathrm{g} / \mathrm{ml}$ ) arsenic-treated groups as compared to their control (Fig. 3). In contrast to these changes that were common in all the arsenic-treated groups, some changes in the form of either loss/gain or intensity difference of loci were unique to or shared with particular treated group(s). For example, gain of $1300 \mathrm{bp}$ locus in the fingerprints of shorttreatment group (Fig. 4, left panel, lanes 2 and 3) and loss of $650 \mathrm{bp}$ locus in the fingerprints of chronic-treatment group (Fig. 4, left panel, lanes 2 and 3) with primer OPC07 was observed in $1 \mathrm{ng}$ and $100 \mathrm{ng} / \mathrm{ml}$ but not in $1 \mu \mathrm{g} / \mathrm{ml}$ arsenictreated samples as compared to the control. The dose-specific alterations in the RAPD loci were gains of $700 \mathrm{bp}$ in $1 \mathrm{ng} / \mathrm{ml}$ (Fig. 4, left panel, lane 2); $1000 \mathrm{bp}$ and $750 \mathrm{bp}$ in $100 \mathrm{ng} / \mathrm{ml}$ (Fig. 4, left panel, lane 3); $900 \mathrm{bp}$ and $500 \mathrm{bp}$ in $1 \mu \mathrm{g} / \mathrm{ml}$ (Fig. 4, left panel, lane 4) of short-term arsenic-treated groups. Similarly, gains of $890 \mathrm{bp}$ in $100 \mathrm{ng} / \mathrm{ml}$ (Fig. 4, right panel, lane 3); $1100 \mathrm{bp}$ in $1 \mu \mathrm{g} / \mathrm{ml}$ (Fig. 4, right panel, lane 4); and loss of $780 \mathrm{bp}$ and $750 \mathrm{bp}$ in $100 \mathrm{ng} / \mathrm{ml}$ (Fig. 4, right panel, lane 3 ) of chronic arsenic-treated groups were dose-specific altered loci in the fingerprints generated by primer OPC07 (Table I). The loss of intensity of $890 \mathrm{bp}$ amplified fragment with primer OPC03 was observed only in the fingerprint of $100 \mathrm{ng}$ arsenic-treated sample (Fig. 3, right panel, lane 3). Interestingly, the loss in the intensity of this amplified locus was also detected in fingerprints generated with primer $\mathrm{OPCO} 3$ from $100 \mathrm{ng} / \mathrm{ml}$ arsenic-treated samples DNA digested with MspI and HpaII (Fig. 5, left panel, lanes 3 and 7), indicating
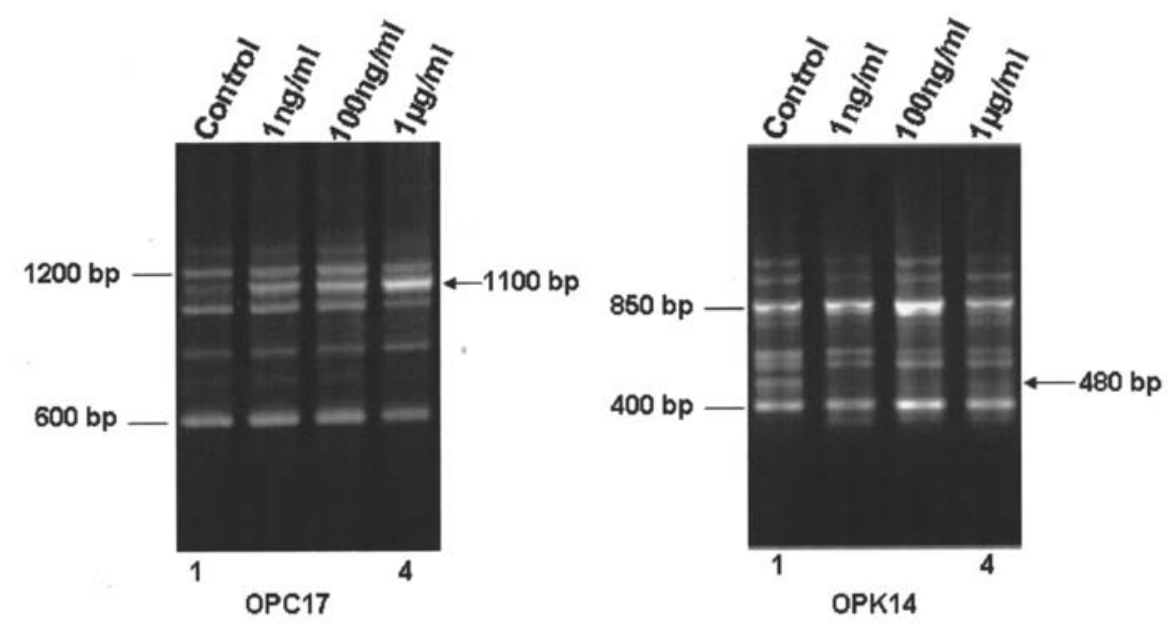

Figure 2. Representative RAPD fingerprints showing arsenic-induced mutational changes as revealed by loss/gain of amplification products from DNA of arsenictreated $(1 \mathrm{ng} / \mathrm{ml}, 100 \mathrm{ng} / \mathrm{ml}, 1 \mu \mathrm{g} / \mathrm{ml})$ cells and their corresponding control. Primers used (OPC17, OPK14) are indicated at the bottom of each fingerprint. The loss/gain of RAPD loci in the fingerprints from arsenic-treated cells are indicated by arrow heads and their sizes (in base pairs, bp) are also shown. 

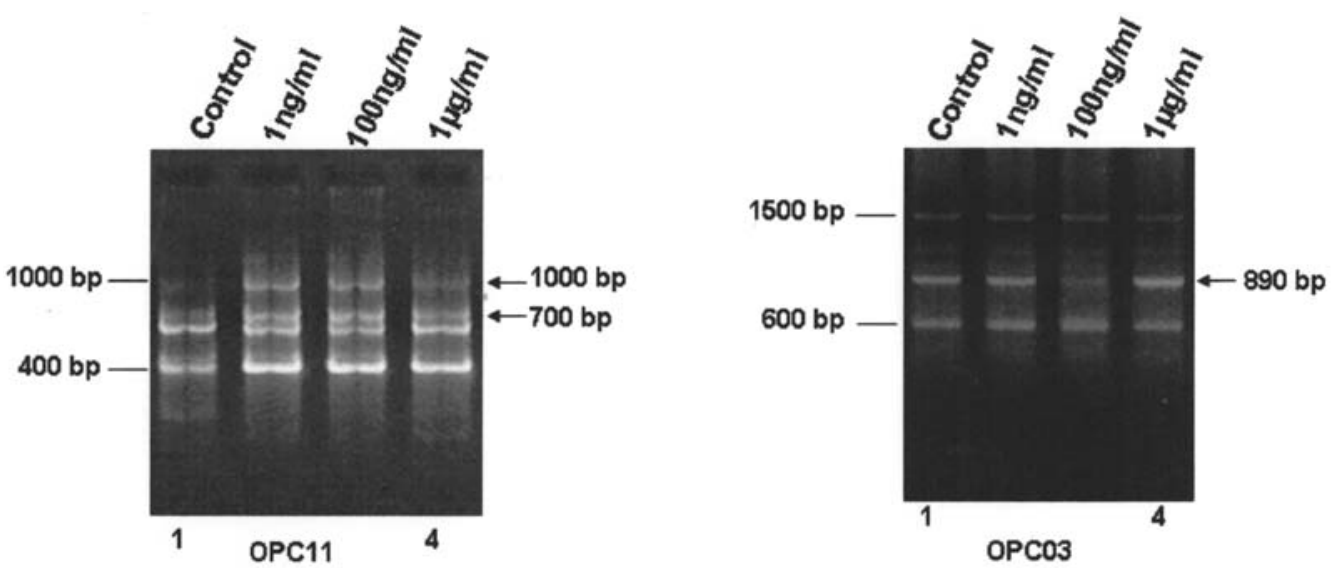

Figure 3. Representative RAPD fingerprints showing arsenic-induced mutational changes as revealed by loss/gain and intensity differences of amplification products from DNA of arsenic-treated $(1 \mathrm{ng} / \mathrm{ml}, 100 \mathrm{ng} / \mathrm{ml}, 1 \mu \mathrm{g} / \mathrm{ml})$ cells and their corresponding control. Primers used (OPC03, OPC11) are indicated at the bottom of each fingerprint. The loss/gain of RAPD loci in the fingerprints from arsenic-treated cells are indicated by arrow heads and their sizes (in base pairs, bp) are also shown.

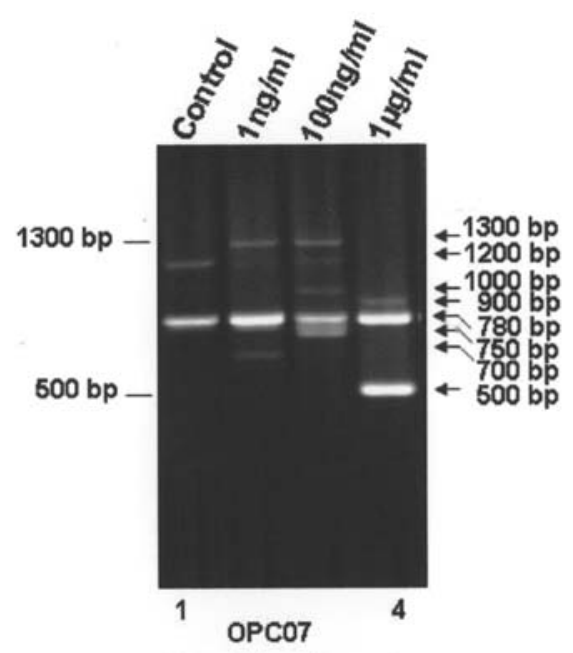

Short Treatment

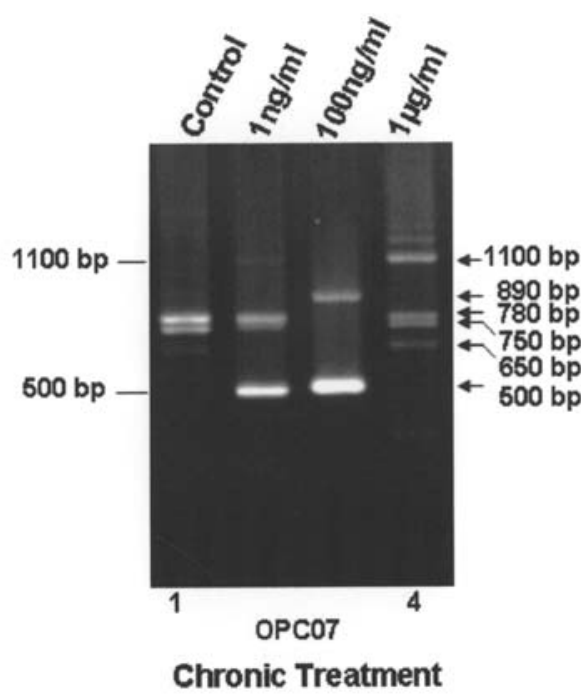

Chronic Treatment

Figure 4. RAPD fingerprints showing arsenic-induced mutational changes as revealed by loss/gain and intensity differences of amplification products from DNA of arsenic-treated $(1 \mathrm{ng} / \mathrm{ml}, 100 \mathrm{ng} / \mathrm{ml}, 1 \mu \mathrm{g} / \mathrm{ml})$ cells and their corresponding control. RAPD fingerprints were generated by primer OPC07 from DNA of cells of shorter arsenic treatement and their control (left panel) as well as from DNA of cells of chronic arsenic treatment and their control (right panel). The loss/gain and intensity differences of RAPD loci in the fingerprints from arsenic-treated cells are indicated by arrow heads and their sizes (in base pairs, bp) are also shown.

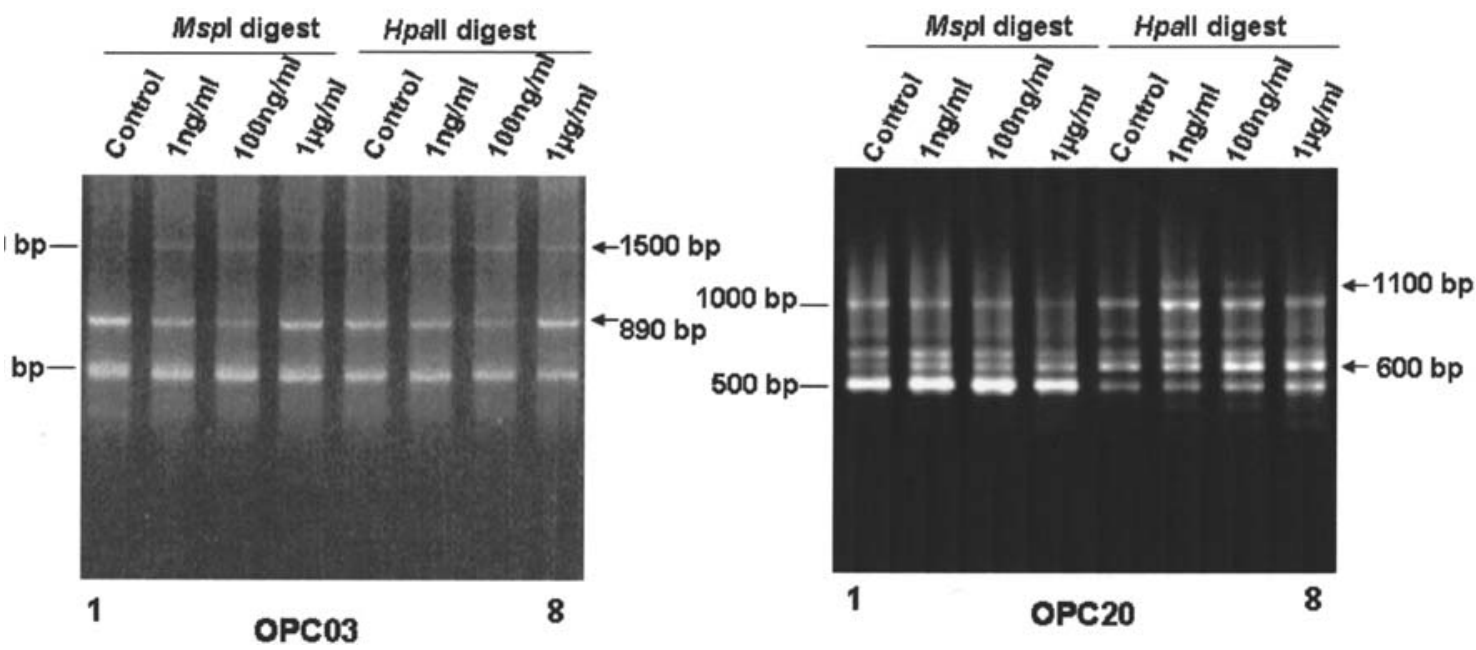

Figure 5. RAPD fingerprints showing arsenic-induced methylation changes as revealed by loss/gain and intensity differences of amplification products from DNA of arsenic-treated $(1 \mathrm{ng} / \mathrm{ml}, 100 \mathrm{ng} / \mathrm{ml}, 1 \mu \mathrm{g} / \mathrm{ml})$ cells and their corresponding control. Primers used (OPC03, OPC20) are indicated at the bottom of each fingerprint. The loss/gain of RAPD loci in the fingerprints from arsenic-treated cells are indicated by arrow heads and their sizes (in base pairs, bp) are also shown. 


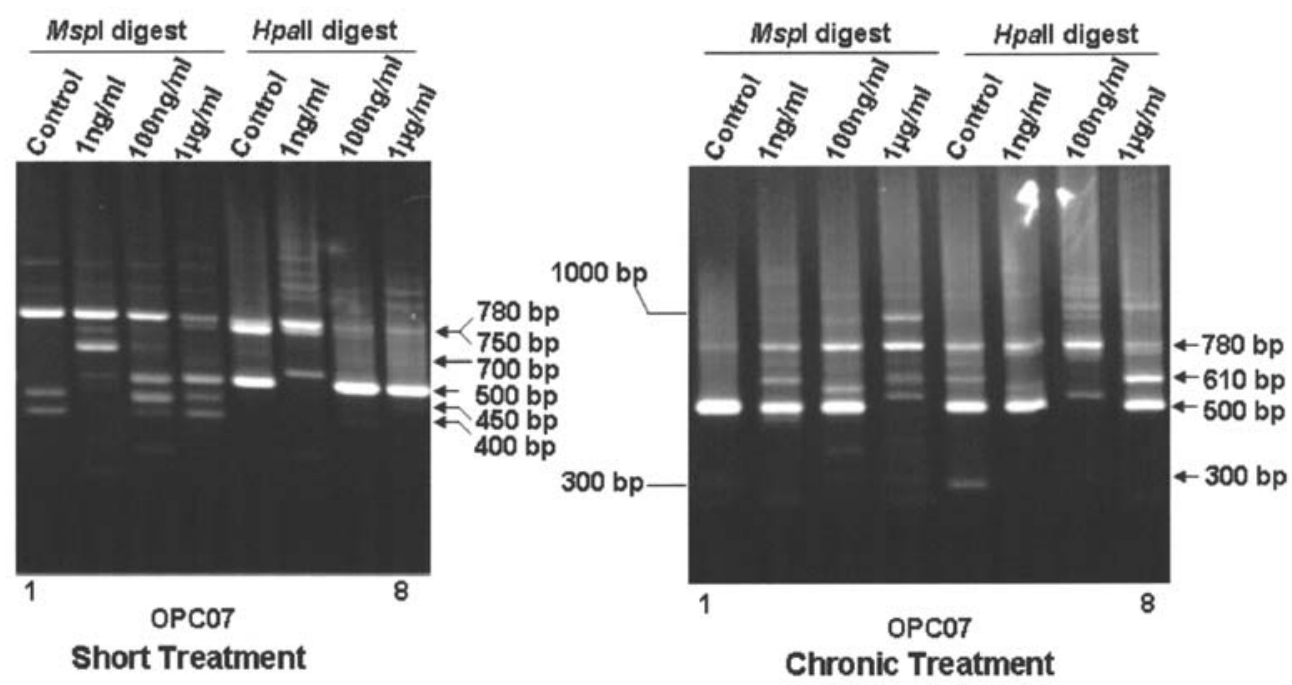

Figure 6. RAPD fingerprints showing arsenic-induced mutational as well as methylation changes as revealed by loss/gain and intensity differences of amplification products from DNA of arsenic-treated $(1 \mathrm{ng} / \mathrm{ml}, 100 \mathrm{ng} / \mathrm{ml}, 1 \mu \mathrm{g} / \mathrm{ml})$ cells and their corresponding controls. RAPD fingerprints were generated by primer OPC07 from DNA of cells of shorter arsenic treatment and their control (left panel) as well as from DNA of cells of chronic arsenic treatment and their control (right panel). The loss/gain and intensity differences of RAPD loci in the fingerprints from arsenic-treated cells are indicated by arrow heads and their sizes (in base pairs, bp) are also shown.

that this genomic region has no site for these restriction enzymes (Table I).

Loci susceptible to arsenic-induced methylation changes. Restriction enzymes MspI and HpaII are isosizomers that recognizes same sequence (CCGG) but differ in methylation sensitivity. If the CG base is methylated, it can be cut by MspI but not by HpaII. Any effect of arsenic on the DNA methylation will change enzyme restriction pattern of template DNA. Thus, comparison of RAPD-PCR fingerprint generated with these two enzymes digested DNA as template will ultimately reflect the methylation changes in arsenic-treated group as compared to their untreated control. We used this strategy to detect the arsenic-induced methylation changes in the genome.

Out of 23 amplification products (loci) generated by 3 primers (OPC03, OPC07, OPC20), 18 loci $(78.26 \%)$ were observed to be variable in the fingerprints generated from MspI and HpaII digested DNA of arsenic-treated samples as compared to the controls (Table I). Out of these 18 loci associated with arsenic-induced methylation changes, 4 loci (700, 510, 450 and 400 bp with primer OPC07, Fig. 6, left panel; Table I) were observed exclusively with shorter treatment of arsenic and 5 loci $(1000,900,610,590,550$ and 300 bp with primer OPC07, Fig. 6, right panel; Table I) were observed exclusively with chronic exposure (100 generations) of arsenic. Both qualitative (loss/gain of loci) and quantitative (loss or gain of intensity of loci) changes were observed in the MspI and HpaII digested DNA from arsenic-treated samples as compared to their controls. For example, a gain of $1500 \mathrm{bp}$ amplified locus with primer OPC03 (Fig. 5, left panel, lanes 2-8) was observed in the fingerprint generated from MSPI digested DNA of arsenic-treated sample as compared to its control. Similarly, the gain of intensity of $600 \mathrm{bp}$ amplified locus with primer OPC20 (Fig. 5, right panel, lanes 2-4) was observed in the fingerprint of MSPI digested DNA of arsenictreated sample as compared to the control. These loci were present with the same intensity in fingerprints of HpaII digested arsenic-treated samples as well as in their control. Thus, the gain of $1500 \mathrm{bp}$ locus with primer OPC03, and the gain in the intensity of 600 bp locus with primer OPC20 in the arsenictreated samples as compared to their control indicates the arsenic-induced hypomethylation of these loci. The absence of $1500 \mathrm{bp}$ locus in the fingerprint of $M s p I$ digested DNA from control indicates that this site is methylated, thus recognized and cut by MSPI, and hence this locus did not get amplified in the fingerprint. Presence of this locus in the fingerprint of HpaII digested DNA from control indicates that HpaII did not make any cut in this locus because this site is methylated, and hence this locus was intact and got amplified in the fingerprint. The presence of this locus in the fingerprints of arsenictreated samples indicates that arsenic-induced hypomethylation in this region to the extent that MspI could no longer cut this site and hence this locus was intact and available for amplification. This explanation also holds true for the gain of intensity of $600 \mathrm{bp}$ amplified locus with primer OPC20 in MspI digested arsenic-treated samples (Fig. 5, right panel). The gain of intensity of $780 \mathrm{bp}$ amplified locus with primer OPC07 in MspI digested DNA from chronic arsenic-treated samples as compared to its control also indicates the arsenicinduced hypomethylation of this site (Fig. 6, right panel). Interestingly, a dose-dependent decrease of this locus was observed in the fingerprint generated from MspI digested samples of short-duration arsenic-treated groups (Fig. 6, left panel).

Loci susceptible to both, arsenic-induced mutations and methylation changes. We also observed some loci that revealed changes between arsenic-treated groups $(1 \mathrm{ng} / \mathrm{ml}, 100 \mathrm{ng} / \mathrm{ml}$, $1 \mu \mathrm{g} / \mathrm{ml})$ as compared to their control. For example, gain of $700 \mathrm{bp}$ amplification product with primer OPC07 was observed only in the $1 \mathrm{ng} / \mathrm{ml}$ arsenic-treated group from undigested DNA (Fig. 4, left panel, lane 2) as well as MspI digested DNA (Fig. 6, left panel, lane 2) as compared to their controls and this locus was absent in HpaII digested DNA (Fig. 6, right 
panel). Presence of this locus in the $1 \mathrm{ng} / \mathrm{ml}$ arsenic-treated sample as compared to its control can be explained by the mutation in this locus. Additionally, the presence of this locus in MspI digest and its absence in HpaII digest can be explained by the hypomethylation at the priming site of this locus. Arsenic-induced hypomethylation has resulted into HpaII mediated cut at priming site and loss of priming and ultimately no amplification of this locus.

Similarly, the presence of $610 \mathrm{bp}$ amplified locus in the fingerprint generated with primer OPC07 from $\mathrm{HpaII}$ digested DNA of control (Fig. 6, right panel, lane 5) and its absence in fingerprint of MspI digested DNA of control (Fig. 6, right panel, lane 1) from chronic treated batch of cells indicate endogenous methylation of this site. Presence of this locus in the fingerprint generated from MspI digested DNA of $1 \mathrm{ng} / \mathrm{ml}$ arsenic-treated samples (Fig. 6, right panel, lane 2) indicate arsenic-induced hypomethylation of this site. However, the presence of a smaller than $610 \mathrm{bp}$ locus in the remaining arsenic-treated samples, $\sim 600 \mathrm{bp}$ in $100 \mathrm{ng} / \mathrm{ml}$ (Fig. 6, right panel, lane 3), and $\sim 580$ bp in $1 \mu \mathrm{g} / \mathrm{ml}$ (Fig. 6, right panel, lane 4) indicates that in addition to methylation, mutational changes has also taken place in this locus.

\section{Discussion}

This is the first comprehensive analysis of mutational as well as methylation changes at genome-wide level in any arsenicexposed mammalian cells. In this study, we report direct molecular evidence for arsenic-induced mutations as well as methylation changes in the mouse testicular Leydig cell genome. These genetic and epigenetic changes were observed in low as well as high doses of arsenic and also with short as well as chronic exposure (33 and 100 generations respectively) of cells to arsenic.

Arsenic exposure has been shown to induce DNA hypomethylation in human prostate epithelial cells (8) and mouse liver tissue (11). Arsenic-induced DNA hypermethylation of the promoters of tumor suppressor genes RASSF1A and PRSS3 and its association with human bladder cancer patients has also been suggested (12). Our finding of changes in amplified loci in the fingerprint of MspI/HpaII digested DNA from arsenic-treated samples as compared to their control further supports the potential of arsenic to induce both hypoas well as hyper-methylation in the genome. Moreover, hypomethylation changes induced by lower dose of arsenic at relatively shorter exposure time, as observed in this study is a significant finding.

Previous studies with Drosophila as well as with bacterial and mammalian cell mutation assays have shown that arsenic alone fails to behave as a point mutagen and thus it was classified largely as an epigenetic carcinogen (24-26). However, in another recent study, evidence was reported on the chromosomal aberrations in bone marrow cells of arsenic exposed rats (13). These observations provide no information about specific DNA sequence or gene loci that have undergone mutational changes. Despite these large numbers of studies, the direct evidence at DNA sequence level for the arsenic-induced mutations is lacking. Our study revealed $46 \%$ of the total loci amplified (18 out 39 loci) that were altered in the fingerprints generated from undigested DNA of arsenic-treated cells compared to their control cells. This higher number of loci showing changes in the finger-prints as detected by primers used in this study including primer OPC07 even in relatively shorter treatment duration and lower dose $(1 \mathrm{ng} / \mathrm{ml})$ of arsenic indicates that arsenic is a potent mutagen. Additionally, this is the first comprehensive study that has not only provided strong evidence at the DNA level for the mutagenic potential of arsenic but has also identified the affected loci. Further characterization of these affected loci would be helpful in understanding the genetic mechanism of arsenic-induced carcinogenesis.

The technical limitation could explain why many previous studies failed to detect arsenic-induced mutation despite its strong mutagenic potential. Most of the earlier studies for mutational analysis of arsenic-treated samples were designed to screen mutation in a particular gene or genomic region(s). Since mutation is a random phenomenon, its targets can not be predicted. Thus, any study designed to limit mutation screening in a particular gene or genomic region may not detect mutations that may be present in other than that particular genomic region. In this context, RAPD-PCR is a better approach since it is not biased to any particular gene/genomic region and hence mutation can be screened at genome-wide level. This has been proved practically in this study as well as in our previous study showing strong mutagenic potential of diethylstilbestrol (DES), an estrogenic-chemical that induces renal tumor in Syrian hamster $(21,22)$.

We observed changes in some loci that were only from short-term arsenic exposed cells but not in long-term arsenic exposed cells. We also observed the reversal of some changes, such as, increase in the intensity of loci in short-term exposure and decrease in the intensity of same loci in long-term exposure. These transient genetic changes in short-term exposed cells or the reversal of genetic changes between short-term vs. long-term exposed cells can be associated with the increase tolerance and adaptation of cells over time. Our argument is supported by a previous report showing that long-term exposure to low doses of arsenite resulted in increased tolerance of acute arsenic exposure (27).

In summary, our results demonstrate that not only the long-term but relatively short-term exposure to low doses of arsenic can cause both genetic (mutations) as well as epigenetic (methylation) changes. Further characterization of the loci susceptible to arsenic-induced genetic and epigenetic changes as identified in this study would help to understand the genetic pathway involved in arsenic-induced carcinogenesis.

\section{Acknowledgements}

This work was supported by NIH grant \#RR03045.

\section{References}

1. IARC: Arsenic and arsenic compounds. In: IARC Monograph on the Evaluation of the Carcinogenic Risk to Humans - Overall Evaluations of Carcinogenicity, an Update of IARC Monographs 1 to 42. Lyon, Suppl 7, pp100-106, 1987.

2. National Research Council: Arsenic in drinking water. Update, National Academy Press, Washington, DC, 2001.

3. Chan PC and Huff J: Arsenic carcinogenesis in animals and in humans: mechanistic, experimental, and epidemiological evidence. Environ Carcin Ecotox Rev 9: 83-122, 1997. 
4. Gebel T: Confounding variables in the environmental toxicology of arsenic. Toxicology 144: 155-162, 2000.

5. Lewis DR, Southwick JW, Ouellet-Hellstrom R, Rench J and Calderon RL: Drinking water arsenic in Utah: cohort mortality study. Environ Health Perspect 107: 359-365, 1999.

6. Morales KH, Ryan L, Kuo TL, Wu MM and Chen CJ: Risk of internal cancers from arsenic in drinking water. Environ Health Perspect 108: 655-661, 2000.

7. Chien C, Chiang MC, Ho IC and Lee TC: Association of chromosomal alterations with arsenite-induced tumorigenicity of human $\mathrm{HaCaT}$ keratinocytes in nude mice. Environ Health Perspect 112: 1704-1710, 2004.

8. Benbrahim-Tallaa L, Waterland RA, Styblo M, Achanzar WE, Webber MM and Waalkes MP: Molecular events associated with arsenic-induced malignant transformation of human prostatic epithelial cells: aberrant genomic DNA methylation and K-ras oncogene activation. Toxicol Appl Pharmacol 206: 288-298, 2005 .

9. Kitchin KT: Recent advances in arsenic carcinogenesis: modes of action, animal model systems, and methylated arsenic metabolites. Toxicol Appl Pharmacol 172: 249-261, 2001.

10. Rossman TG: Mechanism of arsenic carcinogenesis: an integrated approach. Mutat Res 533: 37-65, 2003.

11. Chen H, Li S, Liu J, Diwan BA, Barratt JC and Waalkes MP: Chronic inorganic arsenic exposure induces hepatic global and individual gene hypomethylation: implications for arsenic hepatocarcinogenesis. Carcinogenesis 25: 1779-1786, 2004.

12. Marsit CJ, Karagas MR, Danaee H, Liu M, Andrew A, Schned A, Nelson HH and Kelsey KT: Carcinogen exposure and gene promoter hypermethylation in bladder cancer. Carcinogenesis 27: 112-116, 2006

13. Patolla AK and Tchounwou PB: Cytogenetic evaluation of arsenic trioxide in Sprague-Dawley rat. Mutat Res 587: 126-133, 2005.

14. Sciandrello G, Caradonna F, Mauro M and Barbata G: Arsenicinduced DNA hypomethylation affects chromosomal instability in mammalian cells. Carcinogenesis 25: 413-417, 2004.

15. Mure K, Uddin AN, Lopez LC, Styblo M and Rossman TG: Arsenite induces delayed mutagenesis and transformation in human osteosarcoma cells at extremely low concentrations. Environ Mol Mutagen 41: 322-331, 2003.
16. Lengaur C, Kinzler KW and Volgelstein B: Genetic instabilities in human cancers. Nature 396: 643-649, 1998.

17. Schar P: Spontaneous DNA damage, genome instability, and cancer - when DNA replication escapes control. Cell 104: 329-332, 2001.

18. Cahill DP, Kinzler KW, Volgelstein B and Lengaur C: Genetic instability and Darwinian selection in tumors. Trends Cell Biol 9: 57-60, 1999.

19. Uys P and van Helden PD: On the nature of genetic alterations required for the development of esophageal cancer. Mol Carcinog 36: 82-89, 2003

20. Singh KP and Roy D: Identification of novel breast tumorspecific mutations in the q11.2 region of chromosome 17 by RAPD/AP-PCR fingerprinting. Gene 269: 33-43, 2001.

21. Singh KP and Roy D: Somatic mutations in stilbene estrogeninduced Syrian hamster kidney tumors identified by DNA fingerprinting. J Carcinog 3: 4, 2004

22. Singh KP, Lopez-Guerrero JA, Llombart-Bosch A and Roy D: Age, sex and co-exposure to N-ethyl-N-nitrosourea influence mutations in the Alu repeat sequences in diethylstilbestrol-induced kidney tumors in Syrian hamsters. Mutagenesis 19: 67-73, 2004.

23. Singh KP and Roy D: Detection of mutation through RAPD in human and experimental animal tumor samples depends upon the type of Taq DNA polmerases used. Int J Oncol 14: 753-758, 1999.

24. Rizki M, Kossatz E, Velazquez A, Creus A, Farina M, Fortaner S, Sabbioni E and Marcos R: Metabolism of arsenic in Drosophila melanogaster and the genotoxicity of dimethylarsenic acid in the Drosophila wing spot test. Environ Mol Mutagen (In press).

25. Rossman TG, Stone D, Molina M and Troll W: Absence of arsenite mutagenicity in E. coli and Chinese hamster ovary cells. Environ Mutagen 2: 371-379, 1980.

26. Fischer JM, Robbins SB, Al-Zoughool M, Kannamarath SS, Stringer SL, Larson JS, Caruso JA, Talaska G, Stambrook PJ and Stringer JR: Co-mutagenic activity of arsenic and benzo [a] pyrene in mouse skin. Mutat Res 588: 35-46, 2005.

27. Romach EH, Zhao CO, Del Razo LM, Cebrian ME and Waalkes MP: Studies on the mechanisms of arsenic-induced self tolerance developed in liver epithelial cells through continuous low-level arsenite exposure. Toxicol Sci 54: 500-508, 2000. 